\title{
Analysis of technical efficiency in maize production in Guji Zone: stochastic frontier model
}

\author{
Aschalew Shiferaw Belete * (1)
}

\begin{abstract}
Background: The Guji Zone in particular and Oromia region in general have a huge potential for crop production that can even contribute for the country as a whole in the struggle for achieving food security. Maize is Ethiopia's largest cereal crop in terms of total production, acreage, and the number of farm holdings. It is one of the staple crops produced in the study area. However, the farm productivity per hectare is low compared to the national average which indicates the presence of farming inefficiency in the study area. Thus, this study was undertaken with the objective of estimating the level of farmers'technical efficiency in maize production and identifying the factors which determine the variation in the level of technical efficiency among the farmers.

Results: This study was relied on the primary data collected from a sample of maize producing farm household of Adola Rede and Anna Sorra districts of the Guji Zone using a survey questionnaire. A simple random sampling technique was found appropriate for selecting the respondents, since the populations of these study area are homogeneous. The analysis was relied on a cross-sectional data collected from 234 sample farm households. A one-step stochastic frontier normal/truncated-normal model was used to estimate the farmers'technical efficiency as well as to identify the determinants of yield per hectare of maize which was estimated by maximum-likelihood method. The empirical result indicates that there are large numbers of inefficient farmers in both districts. The estimated technical efficiency for maize producing farmers is equal to $69.03 \%$. Besides, the current study revealed that $69.23 \%$ of maize producing farmers have been operating within a technical efficiency score interval equal to (0.5-0.75) in both districts. In addition, the maize yield per hectare in the study area is very low compared to the national average, i.e., the mean yield is 19.2 quintal per hectare. Moreover, the maximum-likelihood results show that gender of the head of the household, age of the head of the household, farm income, row planting, access to credit, number of active labor force, land size owned, access to improved seed and seed type used, and number of livestock were significantly determine the farmers technical inefficiency.
\end{abstract}

Conclusion: The results of the study revealed that there is an opportunity which is being squandered in maize production in the study area. For instance, with a given technology, it is possible to raise the maize yield per hectare by $30.07 \%$ in the study area. Thus, the government and any concerned stakeholders should facilitate access to improved seed and fertilizer, credit, farm technology, and short-term training. Besides, all stakeholders should work in a cooperative and organized manner to implement the full agricultural package on farm level.

Keywords: Technical efficiency, Stochastic frontier model, Maize, Guji Zone 


\section{Background}

In Ethiopia, the farmers have preferred for many years an expanding their farm size through clearing the forest and cultivation of the fragile marginal land to achieve their household's food security. This practice contributes a lot for environmental degradation and variability of elements of weather and climate. Although there is an improvement during the last decade, the Ethiopian government had not succeeded in achieving food security for its citizens especially at household level. Multiple consecutive seasons of below-normal rainfall-in part due to El Nino-have led to the worst drought in more than 50 years across the northeastern and central parts of the country. Low crop production, poor pasture regeneration and livestock health, and water shortages have all contributed to the deteriorating food security situation and severe humanitarian crisis [34].

Farming practices and the use of farming technology in Ethiopia are still at lower stage of development. Despite this problem, Ethiopia's agricultural sector has witnessed consistent growth since 2003: maize production has expanded at $6 \%$ per annum, and the aggregate export values across all commodities have grown at $9 \%$ per annum. Conversely, the farm productivity per hectare is very low as compared to other African countries. For example, in terms of maize productivity per hectare, South Africa's yields (3.77 tons/ha) are relatively higher compared to Ethiopia which is 3.06 tons/ha [17]. These results indicate that both countries are operating below the maximum potential grain yield which ranges from 7-12 tons/ha [1]. What is more is that, maize plays a crucial role in Ethiopia's food security and it is the staple crop with the greatest production, i.e., 4.2 million tons in $2017 / 18$, compared to teff which is 3.0 million tons and sorghum which is 2.7 million tons [28].

An effective maize production sector development could push Ethiopia's food production to quickly reduce the national food deficit and keep pace with a growing population. Empirical literature revealed that successful maize production depends on the correct application of production inputs that would sustain the environment as well as agricultural production [13]. The researchers believe that wheat and maize are the two very important staple crops produced in the current study areas, i.e., Anna Sorra and Adola Rede districts. These areas have huge potential for producing surplus for the market if proper research-based assistant is provided to the farmers. Increasing productivity and efficiency depends on several factors including farm characteristics, socioeconomic characteristics of the farmer, government policies, and other institutional factors. Thus, for one to design better policy measures aimed at increasing productivity, it is important to understand the magnitude of inefficiencies and the factors that influence it.

In this regard, few attempts have been made to measure/quantify the level of technical efficiency in Ethiopia in general and in Oromia region particularly. For instance, in Moretina-Jirru District of Central Ethiopia, the mean technical efficiencies of large wheat farm estimated to be 0.84 . For small farm size, the mean technical efficiency is 0.76 [1]. According to Geta et al. [20], the maize producing farmers' average technical efficiency in southern Ethiopia is only 40\%, whereas Alene and Hassan [5] have showed that the maize producing farmers' average technical efficiency in western Ethiopia is $76 \%$. These suggest that farmers are not operating on the production possibility frontier and there is a considerable potential to increase the productivity of maize with the existing technologies and inputs. Sub-optimal agricultural practices constrain the ability of farmers to improve yields, and over $97 \%$ of cultivation is rain-fed, making the sector highly vulnerable to challenging weather patterns [7]. Achieving the broad-based economic growth requires the ability to efficiently utilize the available resources. This requires a policy intervention which is supported by a research. By estimating the magnitude of technical efficiencies and examining the factors that influence such resultant inefficiency levels, this paper aims to provide the way forward to increasing maize farm productivity. Thus, this research addressed the following research questions: How much opportunity is being squandered due to the variation in the level of efficiency among the farmers? What are the determinants of technical inefficiency among maize producing farmers?

\section{Objectives of the study}

- To provide baseline information about the level of farming inefficiency in the study area by estimating technical inefficiency score in maize production.

- To examine the determinants of technical inefficiency in maize production

\section{Literature review}

The economic theory of production provides the analytical framework for most empirical research on productivity and efficiency. Efficiency means the realization of a production goal without waste. Beginning with this basic idea of "no waste", economists have built up a variety of theories of efficiency. The basic idea underlying all efficiency measures, however, is that of the quantity of goods and services per unit of input. Accordingly, a production unit is said to be technically inefficient if too little output is being produced from a given bundle of inputs. There 
are two basic methods of measuring efficiency-the classical approach and the frontier approach. The classical approach is based on the ratio of output to a particular input, and is termed partial productivity measure. Discontent with the shortcomings of this approach led economists to develop advanced econometric and linear programming methods for analyzing productivity and efficiency. The frontier measure of efficiency implies that efficient firms are those operating on the production frontier. The amount by which a firm lies below its production frontier is regarded as the measure of inefficiency. The earliest work on the frontier approach dates back to [18].

Farrell [18] identified three types of efficiency: technical efficiency, allocative efficiency (price efficiency), and economic efficiency (overall efficiency). Technical efficiency (TE) refers to the ability of a Decision Making Unit (DMU) to produce the maximum feasible output from a given bundle of inputs, or the minimum feasible amounts of inputs to produce a given level of output. The former definition is referred to as output-oriented TE, while the latter definition is referred to as input-oriented TE. Allocative efficiency (AE) refers to the ability of a technically efficient DMU to use inputs in proportions that minimize production costs given input prices. Economic efficiency $(\mathrm{EE})$ is the product of both $\mathrm{TE}$ and $\mathrm{AE}$ [18]. Thus, a DMU is economically efficient if he/she is both technically and allocatively efficient.

Economists argue that the achievement of (greater) efficiency from scarce resources should be a major criterion for priority setting. Decision-makers are increasingly faced with the challenge of reconciling growing demand for various services with available resources. In 1957, Farrell argued that the firm's efficiency can be calculated empirically and he proposed, for the first time, an innovation method of efficiency frontier estimation from real situations of production observations. The frontier estimation methods can be classified according to: the frontier planned form, the estimation technique used to get it and according to the nature and the supposed properties of the gap between the observed production and the optimal production. The classification according to the frontier form permits to distinguish between the parametric approaches and the nonparametric approaches. The parametric approach presents a function including explicit parameters (Cobb-Douglass, CES, Translog, etc.). Aigner et al. [4] indicate that the parametric approach is the one which presents a function including explicit parameters. In the case of a parametric function, many econometrical techniques and non-econometrical ones permit to estimate the production or the cost frontiers parameters: the least-squares method or the maximumlikelihood method.
The nonparametric frontiers have the particularity not to impose any pre-established form to the frontier Battese et al. (1975). The nonparametric approach is then used when the production process cannot be identified by a functional form. The convexity of the production is the only differentiation element of the nonparametric approaches. It makes it possible to distinguish the convex nonparametric approach from that non convex. The former was used by Farrell in 1957 for the first time. The production frontier proposed by Farrell is linear and it imposes some constant outputs at the scale.

Two methods that are the Data Envelopment Analysis and Free Disposal Hull help to estimate the parametric approach of the production frontier. The first method consists in estimating a convex envelop, while the second one permits to arrange the firms in a growing order, so as to estimate a frontier in the form of stairs. The nature of the gaps between the observed production and the maximum production distinguishes the stochastic frontiers from the deterministic frontiers. In fact, if we suppose that the gaps are only explained by the inefficiency of the producer, we qualify the frontier of having a deterministic nature. If, on the contrary, we estimate that the gaps are explained at the same time by the inefficiency of the producer and by some random elements which do not depend on the producer, we say that the frontier has a stochastic nature [29].

In short, a firm or sector efficiency can be measured through some parametric and nonparametric approaches which differ primarily by the assumptions concerning the residues. A production or a cost frontier will be parametric if we impose a deterministic functional form (Cobb-Douglass, Translog, etc.) of we suppose that any gap between the estimated function and the observations is considered as coming from the producer's inefficiency, and stochastic if, the gaps are explained by both the producer's inefficiency and some random elements which are not under the owner's control. The parametric approaches impose a functional form that presuppose the frontier form, whereas the nonparametric approaches impose less structure to the frontier, but they suppose the absence of random errors.

The stochastic frontier production model has been widely used to estimate the technical efficiency of farmers in agricultural researches. Several technical efficiency/ inefficiency studies have been conducted in Ethiopia and other countries. For instance, Bamlaku et al. [8] have analyzed technical efficiency of farmers in three ecological zones in Ethiopia. Access to credit, literacy, proximity to market, and livestock are found to have positive and significant effect, while age, sex, extension service, and offfarm activities are found to have insignificant effect on technical efficiency of farmers. Moreover, Endrias et al. 
[16] have examined technical efficiency of maize farmers in Ethiopia. Based on their estimation, agro-ecology, oxen holding, farm size, and use of improved maize variety are found to be significant, whereas age, education, family size, and access to credit are found to be insignificant determinants of technical efficiency (Fig. 1).

\section{Materials and methods}

\section{Research design and data collection}

This study was undertaken in Guji Zone, Ethiopia. Particularly, the study was conducted in Anna Sorra and Adola Rede districts of the Guji Zone. The two districts area is commonly categorized into highland, midland, and lowland agro-ecological zone as the Guji Zone's administration office report indicated [23]. Both districts have ample potential for crop growing and livestock production as it is witnessed by farmers' ownership of large number of livestock. In addition, the farmers are also nowadays engaged in the production of coffee as means of livelihood.

The study employed quantitative approach and crosssectional survey design. Quantitative techniques rely on collecting data that is numerically based and amenable to such analytical methods as statistical correlations, often in relation to hypothesis testing [36]. Cross-sectional survey design was used for its advantage of measuring current attitudes or practices. It also provides information in a short amount of time, such as the time required for administering the survey and collecting the information [15].
The cross-sectional data were collected from sample farmer households of Anna Sorra and Adola Rede districts using a survey questionnaire. The contents of the survey questionnaire were evaluated by the expertise of agriculture and crop sub-sector ahead of its approval for the data collection. Moreover, a pilot study was undertaken for pre-testing the questionnaire and the questionnaire was revised in light with the results of the pilot study.

In this study, combinations of purposive and simple random sampling techniques were employed. For example, three kebeles from each district were purposively selected, viz., Maleka, Sakarro, and Bilu from Adola Rede and Me'e Melka-Galma, Malka-Dimtu, and Soloolo from Anna Sorra district. These kebeles are the major maize producers in these two districts and hence improving farm level of technical efficiency of maize producing farmers in these kebeles has significant implication on the overall production in the two districts. Then, sample household were selected using a simple random sampling technique. A simple random sampling technique is appropriate in the current study, since the populations of these study areas are homogeneous in terms of the means of livelihood. The analysis was relied on a cross-sectional data collected from 234 sample farm households.

\section{Methods of data analysis}

For the analysis of the data that were collected from the sample respondents, both descriptive statistics and econometric methods were used. Econometrics analysis
Socio-economic and institutional factors:

Farm income, Access to credit, Access to agricultural technology, Livestock ownership, Extension service, etc...

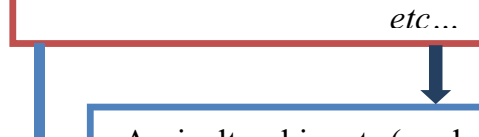

Agricultural inputs (seed, fertilizer, pesticides $\&$ herbicides, man-hours, oxen-hours), etc...
Demographic characteristics (age, gender, education)

Farmers own efforts/commitment (land preparation, weeding repetition), etc...

Technical inefficiency in Maize production

Fig. 1 Conceptual framework. Source: own conceptual mapping 
was used to estimate farmers' technical using stochastic frontier model with maximum-likelihood estimation method. The stochastic frontier normal/truncated-normal model was used to measure the magnitudes and determinants of the inefficiency in maize production.

\section{The Stochastic Frontier Production Model (SFM)}

Farmers in agricultural production aim at maximizing production, minimizing costs, and maximizing profits. Although every producer may attempt to optimize, not all of them may succeed in their efforts in this regard. Given the same inputs and technology, some farmers can produce more efficient than others. Econometrics estimation techniques allow for the fact that deviations of observed choices from optimal ones are due to either failure to optimize (inefficient) or due to random shocks. The SFM produces efficiency estimates or scores of individual producers, thus identifying those who need interventions and corrective measures.

In the literature, this econometric approach has generally been preferred in the empirical application of stochastic frontier production model in agriculture. This is probably due to a number of factors. First, the assumption that all deviations from the frontier arise from inefficiency, as assumed by data envelopment analysis (DEA) is difficult to accept, given the inherent variability of agricultural production due to uncontrollable factors such as weather, pests, and diseases. Second, because many farms are small, family owned farm records are seldom kept. Consequently, available data on production are likely to be subject to measurement errors.

The SFM has significantly contributed to econometric modeling of production and the estimation of technical efficiency in many research fields, especially in agricultural economics. The frontier production model is based on the stochastic efficiency model by Parikh and Shah [32], which, in turn, derives from the composed error model of Aigner et al. [4] and Forsund et al. [19]. The frontier production model begins by considering a stochastic production function with a multiplicative disturbance term of the form:

$$
Y i=f(X i, \beta i) e^{\varepsilon_{i}} .
$$

Taking the natural logarithm of already specified Cobb-Douglas production function, we can reach the following linear production function which can be easily estimated:

$$
\ln Y \mathrm{i}=\beta_{0}+\sum_{\mathrm{j}=1}^{\mathrm{n}} \beta_{\mathrm{j}} \ln \mathrm{X}_{\mathrm{ji}}+\varepsilon_{\mathrm{i}},
$$

where $\ln =$ natural logarithm and $n=1,2, \ldots, 5$ $\boldsymbol{\beta}$ 's are vector of parameters to be estimated and $\boldsymbol{\varepsilon}_{\boldsymbol{i}}$ is a stochastic disturbance term consisting of two independent elements $u$ and $v$, where $u$ is the symmetric component, $v$, accounts for random variation in output due to factors outside the farmer's control, such as weather and diseases. It is assumed to be independently and identically distributed as $N\left(0, \sigma_{v}^{2}\right) \cdot u$ is a one-sided component, where $u \leq 0$ reflects technical inefficiency relative to the stochastic frontier, $f\left(X_{i} ; \beta\right) e^{\varepsilon}$. Thus, $u=0$ for a farm output which lies on the frontier and $u<0$ for one whose output is below the frontier as $\left|N\left(0, \sigma_{u}^{2}\right)\right|$, i.e., the distribution of $u$ is half-normal.

By taking into consideration the entire drawback associated with a two-step estimation method, in the current study, we used a single-step stochastic frontier model estimation technique. According to Kumbhakar and Lovell [29], the two-step procedure has a problem with respect to failure in satisfying the required assumptions.

\section{Definitions and measurement (indicator) of variables used in SFM}

To determine the independent variables to be used in the study, different literatures $[1,16,20,35]$ were reviewed regarding the input-output relationship as well as the factors affecting the inefficiency of farmers. In most of the previous studies, household characteristics, farm characteristics, and institutional factors are hypothesized to explain the inefficiency model. Thus, in this study, the following factors are considered as potential factors affecting farmers' technical inefficiency score (Table 1).

In this study, one of the objectives is to find out the determinants of productivity variation/inefficiency gaps among maize producing farmers. Thus, knowing farmers are technically inefficient alone might not be useful unless the sources of the inefficiency are identified. The inefficiency function is given by the ratio of realized output to stochastic frontier output which can be written as a function of farm and farmer-specific attributes that have impact on farmers' technical inefficiency variation is given as:

$$
T E_{i}=\frac{f\left(X i, \beta_{n}\right) e^{v i-u i}}{f\left(X i, \beta_{n}\right) e^{v i}}=e^{-u i} \Rightarrow e^{f\left(z_{i}, \delta_{i}\right)+\omega_{i}} .
$$

Following Coelli and Battese [9], the inefficiency function can be expressed as:

$$
u_{i}=\delta_{0}+\sum_{j=1}^{n} \delta_{j} z_{j}+\omega_{i},
$$

where $U_{i}$ is inefficiency scores for $i$ th farmer; $Z_{i}$ is vector of explanatory variable which explain the farmers' inefficiency, $\delta_{i}=$ Vector of unknown parameters to 
Table 1 Descriptions and expected sign of the variables

\begin{tabular}{|c|c|c|}
\hline Variables & Descriptions and measures & Expected sign \\
\hline Output (dependent variable) & It indicates the per hectare production of maize. It is measured in quintal & \\
\hline \multicolumn{3}{|l|}{ Lists of independent variables } \\
\hline Land & It shows the amount of land allocated for maize production. It is measured in hectare & + \\
\hline Labor & It is any active labor either hired or family labor participated in farming activities & + \\
\hline Capital & $\begin{array}{l}\text { There is no modern agricultural machinery such as tractor and combiner in the study area, and the } \\
\text { number of pair of oxen involved in maize farming activity is used as a proxy for capital }\end{array}$ & + \\
\hline Fertilizer & $\begin{array}{l}\text { It show the total amount of fertilizer used. In the study, only DAP is used. Use of the recommended } \\
\text { quantities of fertilizer is critical and can have a positive effect on output }\end{array}$ & + \\
\hline Seed & $\begin{array}{l}\text { It indicates the amount of the maize seeds used by the farmers. It can be improved seed or local seed. } \\
\text { It is measured in kg }\end{array}$ & + \\
\hline Tillage repetition & $\begin{array}{l}\text { This indicates efforts exerted by farmers to prepare the land before sowing. As the farmers repeatedly } \\
\text { plow their farm, the soil can become fertile and their farm productivity can be enhanced }\end{array}$ & + \\
\hline Weeding repetition & $\begin{array}{l}\text { This indicates efforts exerted by farmers to clean their farm from weeds. It is usual to see unwanted } \\
\text { plants or weeding in the farm and hence the farmers allocate a considerable amount of their time } \\
\text { to clean it }\end{array}$ & + \\
\hline
\end{tabular}

be estimated, and $\omega_{i}=$ Unobservable random variables, which are assumed to be independently distributed, obtained by truncation of the normal distribution with mean zero and unknown variance, $\sigma_{\omega}^{2}$.

The parameters of the stochastic frontier function are estimated by the method of maximum likelihood, using STATA-12.0. Most efficiency studies have used the Cobb-Douglas production function on the basis of its simplicity (in terms of analysis and interpretation), its ability to handle multiple inputs in its generalized form. Even in the case of imperfections in the market, it does not introduce distortions of its own. Unconstrained Cobb-Douglas production function further increases its potentialities to handle different scales of production. Various econometric problems such as hetroscidasticity and multicolinearity can be handled adequately and easily.

\section{Definitions and measurement of variables used in TEM}

To determine the variables to be included in TEM, a thorough review of various empirical literatures such as $[1,20]$, Alene and Hassan [5] has been conducted and the following variables were hypothesized as variables which affect the farmers' technical inefficiency (Table 2).

\section{Results and discussion}

\section{Descriptive statistical analysis}

The mean maize per hectare yield is about 19.2 quintal with minimum 10 quintal and maximum of 39 quintal production per hectare (see Table 3). According to [21], the national average of maize yield per hectare is 30.2 quintals which show that the maize yield per hectare in the study area is below the national average. The average fertilizer used per hectare for maize production is about
$83 \mathrm{~kg}$ with minimum $30 \mathrm{~kg}$ and maximum of $150 \mathrm{~kg}$ which is also by far deviated from the recommended level. In the study area, on average, a farmers use at least two pairs of oxen per hectare maize production. In this regard, the farmers in the study area make a strong effort for land preparation and weeding. Although there is a difference from farmer to farmer, most of them on average tillage and weed for three times.

On average, the farmers in the study area use $27.5 \mathrm{~kg}$ maize seed per hectare of maize production. As shown in Fig. 2, the majority (92.31\%) of the farmers in the study area have used an improved maize seed. It is known that, in rural areas, the agricultural activity has been practiced by pooling of labors from neighbors and/or relatives not by means of mechanized farming system. In the study area, on average, more than four active labors are involved in per a hectare maize production during the farming season beginning from land preparation to harvesting (see Table 3). On the other hand, land allocated for maize production (in hectare) in the study area on average is more than one hectare.

\section{Empirical analysis Maximum-likelihood estimators}

In this part, the result of econometrics model estimation is presented by comparing the results obtained here with the results found by other studies in various areas. Prior to undertaking detail analysis on these factors the researcher has conducted a test to identify whether or not there is technical inefficiency in maize production using various technical efficiency estimation methods. The researcher hypothesized that there is "no technical inefficiency in maize production" and this test was conducted using the generalized maximum-likelihood ratio 
Table 2 Descriptions and expected sign of the inefficiency variables

\begin{tabular}{|c|c|c|}
\hline Variables & Descriptions and measures & Expected sign \\
\hline Gender of the household head (SEX) & $\begin{array}{l}\text { This is a dummy variable taking a value of } 1 \text { if the household head is male and } 0 \\
\text { otherwise }\end{array}$ & - \\
\hline Age of the household head (AGE) & $\begin{array}{l}\text { This is continuous variable. It is used as an approximation for farming experience of } \\
\text { the households }\end{array}$ & - \\
\hline Years of schooling of the household head (EDU) & $\begin{array}{l}\text { Educated farmers are expected to acquire, analyze \& evaluate information on differ- } \\
\text { ent inputs, outputs \& market opportunities much faster than illiterate farmers }\end{array}$ & - \\
\hline Farm income (INC) & $\begin{array}{l}\text { This is a continuous variable and shows the amount of income the farmers make per } \\
\text { year from their farm }\end{array}$ & - \\
\hline Livestock ownership(NLV) & $\begin{array}{l}\text { This variable represents the number of livestock owned by the household measured } \\
\text { in tropical livestock unit (TLU). Livestock can serve as a means of tillage, harvesting } \\
\text { and transporting inputs and outputs }\end{array}$ & - \\
\hline Agricultural extension workers' contact (EXT) & $\begin{array}{l}\text { Extension workers visit helps the farmer to support them to use better method of } \\
\text { farming, recommended amount of chemical fertilizer utilization among others and } \\
\text { on how to improve the farm productivity in general }\end{array}$ & - \\
\hline Access to credit (CRD) & $\begin{array}{l}\text { This is a dummy variable which takes } 1 \text { if the farmer has access to credit and zero } \\
\text { otherwise }\end{array}$ & - \\
\hline Land size owned (LSH) & This is a continuous variable and shows the amount of land the farmers owned & + \\
\hline Seed types used & $\begin{array}{l}\text { This is a dummy variable which takes } 1 \text { if the farmer adopted improved seed and } \\
\text { zero otherwise }\end{array}$ & - \\
\hline Distance from home to farm (DFM) & $\begin{array}{l}\text { It is the average time which the farmers must travel from residence to their plots. } \\
\text { This is measured in terms of the minutes it takes on foot }\end{array}$ & - \\
\hline
\end{tabular}

Table 3 Maize input-output variables descriptive statistics

\begin{tabular}{|c|c|c|c|c|c|}
\hline Variable & Description & Mean & Std. Dev & Min & Max \\
\hline $\mathrm{MPH}$ & Maize yield per hectare (in quintal) & 19.17069 & 6.738365 & 10 & 38.89 \\
\hline FRTM & Fertilizer used per hectare for maize (in kg) & 83.10343 & 41.86732 & 30 & 150 \\
\hline OXM & Pair of oxen per hectare maize production & 2.593438 & 1.070356 & 0.83 & 6.67 \\
\hline MIP & Maize seed per hectare maize production(in kg) & 27.52996 & 12.87164 & 12 & 80 \\
\hline ALM & $\begin{array}{l}\text { Active labor measured in man hour involved per hectare } \\
\text { maize prod }\end{array}$ & 4.496681 & 2.102776 & 1 & 13.33 \\
\hline Lusm & Land used for maize production (in hectare) & 1.057051 & 0.4685878 & 0.5 & 3 \\
\hline Tillage & Repetition of maize plowing & 2.807692 & 0.6016649 & 2 & 5 \\
\hline Weeding & Repetition of maize weeding & 2.25641 & 0.5183971 & 1 & 4 \\
\hline
\end{tabular}

Source: Own survey result

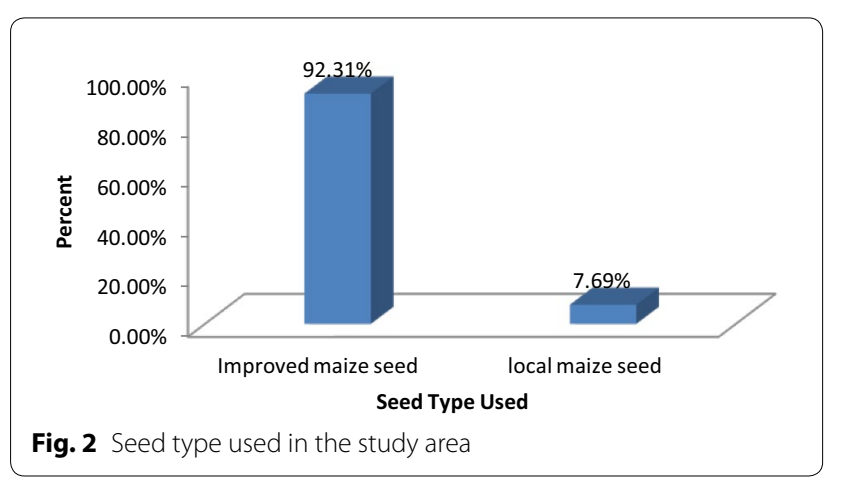

test procedure. However, the generalized maximum -likelihood ratio test was not appropriate for truncatednormal distribution model, since it becomes impossible to evaluate the $\log$ likelihood as $\sigma_{u}^{2}$ approaches zero. Coelli [14] noted that the presence of an inefficiency term would negatively skew the residuals from an OLS regression. By identifying negative skewness in the residuals with the presence of an inefficiency term, Coelli derived a one-sided test for the presence of the inefficiency term. The results of this test are given at the bottom of the output. For this study, the null hypothesis of no inefficiency 
component is rejected in all the three distributional assumptions cases. Rejections of the null hypothesis indicate the presence of technical inefficiency in maize production and hence signify the appropriateness of the stochastic frontier model for this study.

In all the three models, we obtain a value of lambda $(\lambda)$ which is greater than one. The value of $\operatorname{lamda}(\lambda)=\frac{\sigma_{u}}{\sigma_{v}}$ also indicates that maize producing farmers inefficiency is significant in all the three distributions, since it is greater than 1 in all distributions. Moreover, in all the three models, the Prob $>$ chi $2=0.0000$ is highly significant which indicates rejection of the null hypothesis states that the all explanatory variables included in the model are simultaneously equal to zero. The results from half-normal and exponential distribution are almost similar. This was approved by Jondrow et al. [26]. In addition, [22] also found similar result for the two. Therefore, for the analysis of the data in this study, we rely on the truncated-normal model. In the current study, we preferred to use a single-step method of estimation. In the single-step method, both the farm inputs and the variables affecting technical efficiency are combined in the production function and, hence, a single model is estimated. However, in the two-step case, first, the maximum likelihood is used to estimate the Cobb-Douglas function and OLS is used to estimate the determinants of the inefficiency. However, various literatures indicated that a two-step procedure in unreliable in estimation of technical inefficiency. Hence, a single-step procedure is used in the current study.

\section{Result from truncated-normal model}

The maximum-likelihood estimation result of the stochastic frontier normal/truncated-normal model is discussed in Table 4. As we have already indicated above, in this study, a single-step method of estimation is used so as not to face the problems associated with a two-step procedure. The model was fitted with 234 observations and the Prob $>$ chi $2=0.000$ shows the rejection of the null hypothesis which say all parameters are simultaneously equal to zero. Prior to using the stochastic frontier model as final appropriate model, the researcher must first test the null hypothesis which states that "there is no inefficiency". For our case, the null hypothesis is "there is no inefficiency in maize production". The test result is shown in Table 5, and hence, we reject the null hypothesis. This means that there is inefficiency among maize producing farmers in the study area. Therefore, we can use the stochastic frontier model here. The estimate of lambda $(\lambda)=1.2612271$ is greater than one. The value of gamma (0.61399337) shows that about $61.4 \%$ of the farmers' inefficiency in maize production was explained by the variable that included in the model.
All of the explanatory variables used in the output model are significant at $1 \%$ level of significance. The dependent variable used here is $\ln \mathrm{MPH}$ (natural logarithm of maize yield per hectare). The coefficients of the independent variables are explained as follows:

\section{Fertilizer used per a hectare of maize farm (InFRH)}

This variable is significant at $1 \%$ level of significance and its coefficient is positive, indicating that there is a positive relationship between maize productivity per hectare and the amount of per hectare chemical fertilizer used for maize production. The coefficient of amount of chemical fertilizer used for maize production indicates that a $1 \%$ increase in the amount of fertilizer usage for maize production leads to $0.31 \%$ increase in the maize yield per hectare. This result is similar to the result found by Weldegebriel [35] and Abdulai [2].

\section{Maize weeding repetition (InMWR)}

This variable is significant at $5 \%$ level of significance, since its $p$ value is equal to 0.032 and its coefficient is positive, indicating that there is a positive relationship between maize productivity per hectare and the number of times weeding is repeated on a given plot. The coefficient of amount of chemical fertilizer used for maize production indicates that a $1 \%$ increase in the amount of fertilizer usage for maize production leads to $0.12 \%$ increase in the maize yield per hectare. This result is similar to the result found by [3]. Successful cultivation of maize depends largely on the efficacy of weed control. Weed control during the first 6-8 weeks after planting is crucial, because weeds compete vigorously with the crop for nutrients and water during this period [33].

\section{Repetition of tillage (InMPR)}

This variable is significant at $1 \%$ level of significance with $p$ value equal to 0.003 and its coefficient is positive, indicating that there is a positive relationship between maize productivity per hectare and the number of time the plots have been plowed. This means as the farmers' plot is repeatedly plowed their farm, the farm gets fertile and the more it will be productive. The coefficient of amount of tillage repetition in maize production indicates that a $1 \%$ increase in the amount of tillage repetition in maize production leads to $0.18 \%$ increase in the maize yield per hectare. The result found in this study is similar to the study result of Kalinda [27].

\section{Pair of oxen used per a hectare of maize farm (InOHH)}

This variable is significant at $1 \%$ level of significance and its coefficient is positive, indicating that there is 
Table 4 The results of stochastic frontier normal/truncated-normal model

\begin{tabular}{|c|c|c|c|c|c|c|}
\hline \multirow{2}{*}{\multicolumn{4}{|c|}{ Stoc. Frontier normal/truncated-normal model }} & \multicolumn{3}{|c|}{ Number of obs $=234$} \\
\hline & & & & \multicolumn{3}{|c|}{ Wald chi2 $2(7)=1034.75$} \\
\hline \multicolumn{4}{|c|}{ Log likelihood = 97.535577} & \multicolumn{3}{|c|}{ Prob $>$ chi2 $=0.0000$} \\
\hline InMPH & Coef & Std. Err & $z$ & $P>Z$ & & [95\% Conf Interval] \\
\hline \multicolumn{7}{|l|}{$\operatorname{lnMPH}$} \\
\hline $\operatorname{lnFRH} H^{* * *}$ & 0.3056592 & 0.0484493 & 6.31 & 0.000 & 0.2107003 & 0.4006182 \\
\hline $\ln M W^{* *}$ & 0.1061715 & 0.0495665 & 2.14 & 0.032 & 0.009023 & 0.2033201 \\
\hline $\operatorname{lnMPR}{ }^{* * *}$ & 0.1824448 & 0.0609982 & 2.99 & 0.003 & 0.0628906 & 0.301999 \\
\hline $\mathrm{InOHH} \mathrm{H}^{* * *}$ & 0.2316195 & 0.0523811 & 4.42 & 0.000 & 0.1289544 & 0.3342847 \\
\hline $\operatorname{lnMHH} H^{* *}$ & 0.0971334 & 0.0459175 & 2.12 & 0.034 & 0.0071368 & 0.1871301 \\
\hline $\ln M \mid H^{* * *}$ & 0.1048717 & 0.038228 & 2.74 & 0.006 & 0.0299461 & 0.1797973 \\
\hline $\ln L M Z^{* * *}$ & 0.9209692 & 0.0371639 & 24.78 & 0.000 & 0.8481293 & 0.9938091 \\
\hline _cons & 0.0442006 & 0.2631521 & 0.17 & 0.867 & -0.471568 & 0.5599693 \\
\hline \multicolumn{7}{|l|}{$\mathrm{mu}$} \\
\hline SEX* & -0.7442135 & 0.4121561 & -1.81 & 0.071 & -0.0635977 & 1.552025 \\
\hline $\mathrm{AGE}^{* *}$ & -0.0202774 & 0.0102945 & -1.97 & 0.049 & -0.0404541 & -0.0001006 \\
\hline EDU & -0.0165539 & 0.0154354 & -1.07 & 0.284 & -0.0468068 & 0.0136991 \\
\hline $\mathrm{TNR}^{* *}$ & -0.0729732 & 0.0294028 & -2.48 & 0.013 & -0.0153448 & -0.1306016 \\
\hline$I N C^{* * *}$ & $-4.70 e-06$ & $1.28 \mathrm{e}-06$ & -3.66 & 0.000 & $-7.21 e-06$ & $-2.18 \mathrm{e}-06$ \\
\hline $\mathrm{ROW}^{*}$ & -2.356616 & 1.314223 & -1.79 & 0.073 & -4.932445 & 0.219213 \\
\hline $\mathrm{CRD}^{* *}$ & -0.012532 & 0.0057474 & -2.18 & 0.029 & -0.0012674 & 0.0237966 \\
\hline EXV & 0.4646291 & 0.3606043 & 1.29 & 0.198 & -0.2421423 & 1.171401 \\
\hline$N A L^{*}$ & -0.2381318 & 0.1410953 & -1.69 & 0.091 & -0.5146734 & 0.0384098 \\
\hline $\mathrm{LSH}^{* *}$ & 0.3566474 & 0.1598629 & 2.23 & 0.026 & 0.043322 & 0.6699729 \\
\hline $\mathrm{IMD}^{* *}$ & -1.529624 & 0.6312622 & -2.42 & 0.015 & -2.766875 & -0.2923727 \\
\hline DFM & 0.3126582 & 0.4873519 & 0.64 & 0.521 & -0.6425339 & 1.26785 \\
\hline$N L V^{*}$ & -0.0066951 & $0.040,327$ & -1.66 & 0.097 & -0.014599 & 0.0012089 \\
\hline _cons ${ }^{* * *}$ & 0.4632954 & 0.094953 & 4.88 & 0.000 & 0.2771907 & 0.6494001 \\
\hline /Insigma2 & -2.737034 & 0.185183 & -15.68 & 0.000 & -3.363453 & -2.637549 \\
\hline /ilgtgamma & -0.0194481 & 0.4361717 & -0.02 & 0.983 & -0.864329 & 0.8454328 \\
\hline $\begin{array}{l}\underset{s i g m a 2}{ }\left(\sigma_{S}^{2}=\sigma_{u}^{2}+\sigma_{v}^{2}\right)\end{array}$ & 0.0647621 & 0.0092151 & & & 0.0346155 & 0.0715364 \\
\hline $\operatorname{Gamma}\left(\gamma=\frac{\sigma_{u}^{2}}{\sigma_{s}^{2}}\right)$ & 0.61399337 & 0.1090405 & & & 0.2964357 & 0.6996082 \\
\hline sigma_u2 & 0.0397635 & 0.0097377 & & & 0.0056779 & 0.0438491 \\
\hline sigma_v2 & 0.0249986 & 0.0024699 & & & 0.0201577 & 0.0298395 \\
\hline \multicolumn{7}{|c|}{$\operatorname{lamda}(\lambda)=\frac{\sigma_{u}}{\sigma_{v}}=\frac{0.1994}{0.1581}=1.2612271$} \\
\hline
\end{tabular}

${ }^{*}, * *$, and ${ }^{* * *}$ means significant at 10,5 , and $1 \%$, respectively

Source: Own survey result.

a direct relationship between maize productivity per hectare and the amount of hours pairs of oxen were used for maize production. The coefficient of amount of plots used for maize production indicates that a $1 \%$ increase in the amount of hours pairs of oxen used for maize production leads to $0.23 \%$ increase in the maize yield per hectare. The results of the current study are found similar with study conducted by Endrias et al. [16].

\section{Active labor used for maize production (InMHH)}

This variable is significant at $1 \%$ level of significance with $p$ value equal to 0.034 and its coefficient is positive, indicating that there is a direct relationship between 
Table 5 MLE of the Cobb-Douglas SFP with various distributions of inefficiency term

\begin{tabular}{|c|c|c|c|}
\hline Variable & Truncated normal distribution & Exponential distribution & Half normal distribution \\
\hline \multicolumn{4}{|l|}{$\log M Z O$} \\
\hline $\log F R H$ & $\begin{array}{l}0.26212167^{* * *} \\
0.050\end{array}$ & $\begin{array}{l}0.26210081^{* * *} \\
0.050\end{array}$ & $\begin{array}{l}0.26504656^{* * *} \\
0.050\end{array}$ \\
\hline $\log M W R$ & $\begin{array}{l}0.08555118 \\
0.051\end{array}$ & $\begin{array}{l}0.08555151 \\
0.051\end{array}$ & $\begin{array}{l}0.08578216 \\
0.052\end{array}$ \\
\hline $\log M P R$ & $\begin{array}{l}0.23795927^{* * *} \\
0.063\end{array}$ & $\begin{array}{l}0.23796861^{* * *} \\
0.063\end{array}$ & $\begin{array}{l}0.24015062^{* * *} \\
0.063\end{array}$ \\
\hline $\log \mathrm{OHH}$ & $\begin{array}{l}0.27597429^{* * *} \\
0.053\end{array}$ & $\begin{array}{l}0.27596657^{* * *} \\
0.053\end{array}$ & $\begin{array}{l}0.27548877^{* * *} \\
0.053\end{array}$ \\
\hline $\log \mathrm{MHH}$ & $\begin{array}{l}0.11967841^{*} \\
0.048\end{array}$ & $\begin{array}{l}0.11967462^{*} \\
0.048\end{array}$ & $\begin{array}{l}0.11629394^{*} \\
0.048\end{array}$ \\
\hline $\log \mathrm{MIH}$ & $\begin{array}{l}0.1169028^{* *} \\
0.040\end{array}$ & $\begin{array}{l}0.11696768^{* *} \\
0.040\end{array}$ & $\begin{array}{l}0.11222277^{* *} \\
0.040\end{array}$ \\
\hline $\log \mathrm{LMZ}$ & $\begin{array}{l}0.88538574^{* * *} \\
0.037\end{array}$ & $\begin{array}{l}0.88538586^{* * *} \\
0.037\end{array}$ & $\begin{array}{l}0.88488959^{* * *} \\
0.037\end{array}$ \\
\hline _cons & $\begin{array}{l}-0.00900501 \\
0.269\end{array}$ & $\begin{array}{l}-0.00940861 \\
0.269\end{array}$ & $\begin{array}{l}0.04560349 \\
0.269\end{array}$ \\
\hline \multicolumn{4}{|l|}{$\mathrm{Mu}$} \\
\hline $\begin{array}{l}\text {-cons } \\
\text { Ilgtgamma }\end{array}$ & \multicolumn{2}{|c|}{ Ilgtgamma } & \\
\hline $\begin{array}{c}\text { _cons } \\
\text { Insigma2 }\end{array}$ & \multicolumn{3}{|c|}{ Insigma2 } \\
\hline \multicolumn{4}{|l|}{ Insig2v } \\
\hline \multicolumn{4}{|l|}{ Insig2u } \\
\hline _cons & $-5.037093^{* * *}$ & $-3.9101573^{* * *}$ & $-3.9101573^{* * *}$ \\
\hline \multirow[t]{2}{*}{ Legend } & ${ }^{*} p<0.001$ & & \\
\hline & $\begin{array}{l}\text { H0: No inefficiency component: } \\
z=-1.041 \text { Prob }<=z=0.049\end{array}$ & $\begin{array}{l}\text { Likelihood-ratio test of sigma_u=0: } \\
\text { chibar2 }(01)=1.68 \text { Prob }>=\text { chibar2 }=0.027\end{array}$ & $\begin{array}{l}\text { Likelihood-ratio test of } \\
\text { sigma_u }=0: \operatorname{chibar2}(01)=1.16 \\
\text { Prob }>=\text { chibar2 }=0.014\end{array}$ \\
\hline
\end{tabular}

Source: Own estimation.

${ }^{*}, * *$, and ${ }^{* * *}$ means significant at 10,5 , and $1 \%$, respectively

maize productivity per hectare and the amount of man hours employed for maize production. The coefficient of amount of plots used for maize production indicates that a $1 \%$ increase in the amount of man hours spent for maize production leads to $0.09 \%$ increase in the maize yield per hectare. This study is similar to the results of the study found by Idris [24] and Endrias et al. [16].

\section{Maize input per hectare (InMIH)}

This variable is significant at $1 \%$ level of significance with $p$ value equal to 0.006 and its coefficient is positive, indicating that there is a positive relationship between maize productivity per hectare and the amount of maize input used for maize production. The coefficient of amount of maize used for maize production indicates that a $1 \%$ increase in the amount of maize input used for maize production leads to $0.10 \%$ increase in the maize yield per hectare. This study is similar to the results of the study found by Abdulai [2].

\section{Amount of plot allocated for maize production (InLM)}

This variable is significant at $5 \%$ level of significance, since its $p$ value is equal to 0.000 and its coefficient is positive, indicating that there is a positive relationship between maize productivity per hectare and amount of plot allocated for maize production. The coefficient of amount of plots used for maize production indicates that a $1 \%$ increase in the amount of plot used for maize production leads to $0.92 \%$ increase in the maize yield per hectare. Similar studies in which farm size allocated for maize production was significant are Plessis [33] and Weldegebriel [35]. 


\section{The determinants of technical inefficiency in maize production}

To analyze the determinants of technical inefficiency, 13 variables were used in one-step truncated-normal distribution stochastic frontier estimation method. Three variables namely, years of schooling of the head of the household (EDU), distance from home to farm (DFM), and extension visits (EXT). Besides, contrary to our expectation, the coefficient for the variable extension visits (EXT) is positive in our maximum-likelihood estimation. On the other hand, two variables, viz., number of active labor (NAL), row planting (ROW) and number of livestock owned (NLV), are found significant at 10\% level of significance. The remaining hypothesized variables were found significant at $1 \%$ or $5 \%$ level of significance. The interpretations for the other variables were done as follows:

\section{Gender of the household head (SEX)}

This variable is found significant at $10 \%$ level of significance. The expected sign of this variable is negative and the result obtained is in line with the expectation which indicates that gender of the household head being male as compared to female household head can have negative impact on farm in inefficiency. Expressed differently, gender of the household head being male as compared to female household head can have positive impact on farming efficiency. This is due to fact that the agricultural activities in the study areas have been practiced mainly by male and it was even considered as a males' work and, hence, males allocate the majority of their times for outdoor activities in which agriculture is the paramount one. Therefore, this causes the yield per hectare of male -headed household to outweigh the female headed household. This study is similar to the results of the study found by Idris [24].

\section{Age of the head of household (AGE)}

This variable is significant at $5 \%$ level of significance. Age is a proxy variable for farm experience. Higher age is, therefore, an indication of higher farm experience in rural area where agriculture is the main means of livelihood. The expected sign is negative and we obtain a negative coefficient as per the expectation. The negative coefficient higher age leads to a reduction of the inefficiency of maize producing farmers. From the result of the study, a $1 \%$ increase in the age of the head of the household leads to $0.02 \%$ decrease in the technical inefficiency of the farmers. This result is similar to the study by Acquah [3].

\section{Education level of the household head (EDU)}

This variable is not significant at all. The researcher expects a negative sign for this variable and obtained a result which supports the expectation. The farmers who achieved relatively higher education level are believed to have higher exposure to agricultural technology and agricultural technology adoption possibility. This could enhance the farm productivity per hectare, since better educated farmers are more likely to adopt modern equipment efficiently $[11,25]$.

\section{Land tenure security (TNR)}

This variable is significant at 5\% level of significance. The results show that the coefficient for this variable is negative which similar to the expected sign. Negative coefficient indicates obtaining land tenure security will improve the farm productivity per hectare which in turn decreases the farm inefficiency. The farmers who obtain a farm land tenure security certificate are believed to devote their time and exert maximum efforts to take care of their farm. The above table show that coefficient of tenure security (TNR) which is -0.0729732 indicates that compared to the farmers who have no land tenure security, those who were certified have a $0.072 \%$ lower technical inefficiency in maize production. The current finding is consistent with the results by Negatu [30].

\section{Farm income (INC)}

This variable is significant at $1 \%$ level of significance. The results show that the coefficient for this variable is negative which is similar to the expected sign. Farmers need money to purchase seed, fertilizer, pesticides, and herbicides, and to pay for the hired labor in addition to financing the household consumer goods demand. Therefore, higher farm income means higher purchasing power of the farmer to different farm inputs. Hence, higher farm income can reduce the farmers' technical inefficiency in maize production. This study is similar to the results of the study found by Idris [24].

\section{Row planting (ROW)}

This variable is significant at $10 \%$ level of significance. The results show that the coefficient for this variable is negative which is similar to the expected sign. Planting in row has importance in many aspects. It reduces amount of seed input and fertilizer required per hectare and it improves the yield per hectare. Thus, the negative coefficient which we obtained indicates that row planting will decrease the farmers' technical inefficiency in maize production. From the results obtained in our maximumlikelihood estimation coefficient of row planting (ROW) which is equal to -2.356616 indicates that compared to the farmers who practiced a traditional farming system, 
those who were adopted row planting technology have $2.35 \%$ lower technical inefficiency in maize production.

\section{Access to credit (CRD)}

This variable is significant at $5 \%$ level of significance. The results show that the coefficient for this variable is negative which is similar to the expected sign. Sometimes farmers need credit to finance their farm's various input requirements. The regression result obtained in our maximum-likelihood estimation coefficient of access to credit (CRD) which is equal to -0.012532 indicates that compared to the farmers who have no access to credit, those who have access to credit have $0.012 \%$ lower technical inefficiency in maize production. The study conducted by Beyan et al. [12] in Gerawa district obtained similar results to this study in this regard. In addition, this result is similar to the study result found by Acquah [3].

\section{Number of active labor (NAL)}

This variable is significant at $10 \%$ level of significance. The results show that the coefficient for this variable is negative which is similar to the expected sign. Most of the works in farming activities (land preparation, plowing, weeding, harvesting, and transportation of farming inputs and output) require active labor. Hence, having more active labor can lead to an improvement in farm productivity. From the result of the study, a 1\% increase in the number of active labor (NAL) in given household leads to $0.238 \%$ decrease in the technical inefficiency of the farmers in maize production. Beshir [10] found that the number of active labor (NAL) is negatively and significantly affect inefficiency which is similar the result of the current study.

\section{Land size owned in hectare (LSH)}

This variable is significant at $5 \%$ level of significance. The results show that the coefficient for this variable is positive which in line to the expected sign. When the farmers have higher land holding, they rarely invest on improving the land productivity. The result obtained also indicates that a $1 \%$ increase in the land holding size of a farmer increases the farm inefficiency by $0.356 \%$. This study is similar to the results of the study found by Oyewo [31].

\section{Seed types used (IMD)}

This variable is significant at $5 \%$ level of significance. The results show that the coefficient for this variable is negative which similar to the expected sign. Adopting of improved maize can increase the farm yield per hectare. Negative sign which we obtained indicates that farmers who adopted an improved maize seed are less inefficient compared to those who did not adopted improved seed. The regression result obtained in our

$\begin{aligned} & \text { Table } 6 \\
& \text { in mammary } \\
& \text { in production }\end{aligned}$
\begin{tabular}{lllllll} 
Variable & Obs & Mean & Std. Dev & Min & Max \\
\hline $\begin{array}{l}\text { Technical effi- } \\
\text { ciency }\end{array}$ & 234 & 0.6903726 & 0.1174334 & 0.402619 & 0.9999997 \\
\hline
\end{tabular}

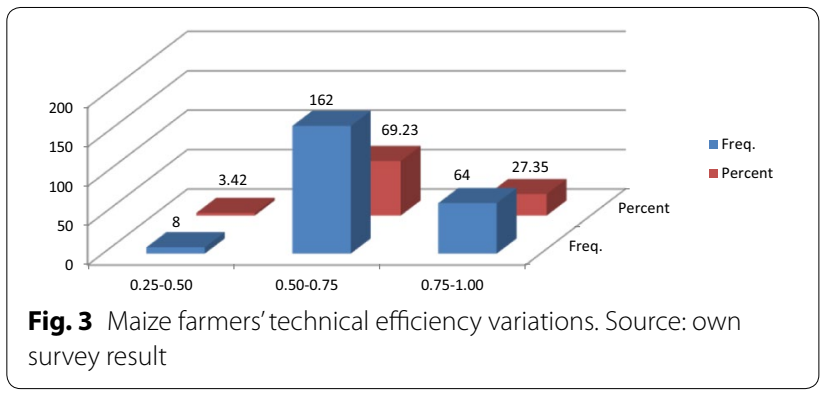

maximum-likelihood estimation coefficient of seed types used (IMD) which is equal to -1.529624 indicates that compared to the farmers who did not adopted improved seed, those who adopted improved maize seed have $1.53 \%$ lower technical inefficiency in maize production. If improved seed is properly applied, it gives higher yield per hectare of maize production. Ali et al. [6] found a result which is consistent with the current study.

\section{Number of livestock (NLV)}

The amount of livestock owned by a farmer is measured by tropical livestock unit (TLU). This variable is significant at $10 \%$ level of significance. The results show that the coefficient for this variable is negative which is similar to the expected sign. Beyan et al. [12] also found a significant and negative coefficient for this variable in the study which they conducted in Gerawa district. For rural households, livestock can be a source of income, a source of food, and a means of transportation, and their manure can be used as compost. Thus, the negative sign for this coefficient indicates that as the number of livestock owned by farmers increased, it leads to reduction in inefficiency of farmers in maize production.

\section{The average technical efficiency in maize production}

Following the estimation, a one-step Stochastic Frontier Normal/Truncated-normal model, we estimate the mean technical efficiency level of maize producing farm households. The result is shown in Table 6.

The mean level of technical efficiency of Maize producers is found to be $69.03 \%$ which indicates that there is a possibility for the maize output to increase by 
$31.07 \%$ at a given level of input consumption. The minimum efficiency score is $40.26 \%$, while the maximum efficiency score is $99.9 \%$. The results from the maximum-likelihood estimate of the frontier model for the study conducted in Ghana showed that averagely, farmers were $67 \%$ technically efficient, implying that $33 \%$ of maize yield was not realized [3]. The study conducted in Nigeria by Idris [24] estimated that the mean technical efficiency in maize production is $69 \%$. Thus, the result of the current study is found similar with study results found in other African country.

As Fig. 3 clearly indicates, the $69.23 \%$ of maize producing farmers were operating with technical efficiency score interval equal to $(0.5-0.75)$ in both districts. In addition, $27.35 \%$ of maize producing farmers were operating at efficiency score level greater than 0.75 . However, the remaining $3.42 \%$ of maize producing farmers were operating with efficiency score level below $50 \%$ of their capacity.

\section{Post estimation of stochastic frontier normal/ truncated-normal model}

i. Kernel density estimation for the half-normal distributional assumption

To make sure whether or not the half-normal distributional assumption is met, a kernel density function is plotted using STATA-12 as follows in Fig. 4 and it proves the assumption that inefficiency effect error term $u_{i}$ is non-negatively distributed with half-normal distribution.

ii. Linktest result for model specification tests of the frontier model

The link test shows that the model has no misspecification problem since _hat is significant at

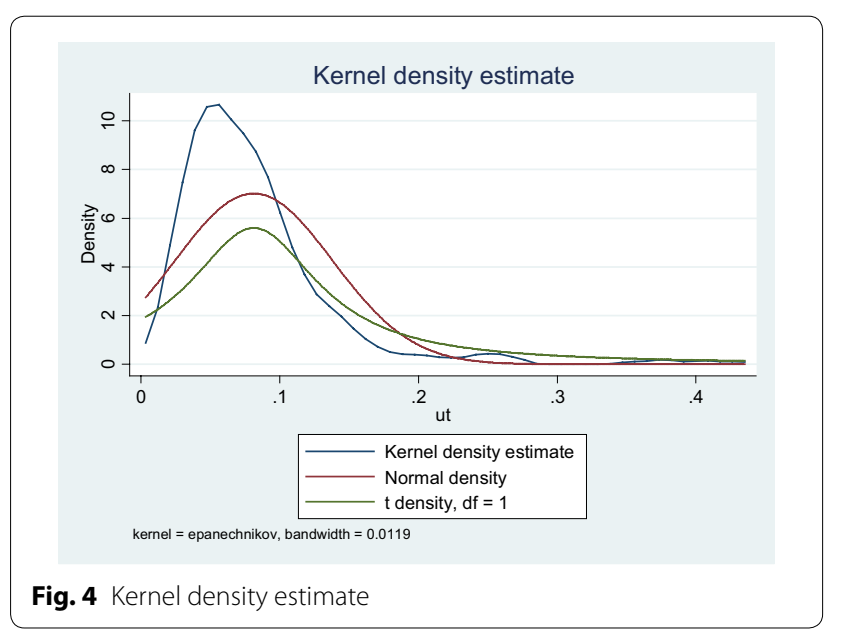

$5 \%$ level of significance and_hatsq is insignificant. The results for the model specification tests of the frontier model are shown in the Additional file 1: Annex I.

\section{Conclusion and recommendation}

The empirical result indicates that maize producers in the Guji Zone were operating with technical inefficiency. For instance, the estimated technical inefficiency score is equal to $69.03 \%$. This shows that, with a given technology, it possible to raise the maize yield per hectare by $30.07 \%$. In addition, the maize yield per hectare is also very low which is compared to the national average, i.e., the mean yield is 19.2 quintal per hectare for maize. Compared to the 30.2 quintal per hectare yield of the national average, the farmers in zone had exhibited low maize farm productivity. Therefore, all stakeholders must work hand in hand to implement the full agricultural package and thereby raise the maize yield.

The agricultural extension workers must provide a genuine support and guidance to farmers to encourage them adopts pre- and post-harvesting agricultural technologies. Moreover, the extension service workers must guide farmers on how to use fertilizer, seed, and pesticides and herbicides. For instance, the average fertilizer used per hectare for maize production is about $83 \mathrm{~kg}$ with minimum $30 \mathrm{~kg}$ and maximum of $150 \mathrm{~kg}$ is by far deviated from the recommended level. Thus, continuous followup and support should be extended to farmers regarding the utilization of the recommended fertilizer and seed amount per hectare.

In addition, provision of a short-term training which is related to farming and their livelihood is also essential for the farmer since it serve as a knowledge transfer. Such knowledge transfer can help the farmers to adopt the agricultural technology and thereby improve their yield per hectare and efficiency. As shown in Table 4, utilization of improved seed significantly affects the farmers' technical efficiency in study areas. Awareness creation about the improved seed utilization coupled with sufficient access to improved input is found essential. Thus, the zonal and/or district levels of agricultural bureau or any concerned stakeholders such as the regional or local government and any training institutions should identify the skill gap and provide training for the farmers.

Row planting is one of the variables which is found significantly affecting the farmers' technical efficiency in the production of maize in the zone (see Table 4). However, till now, a significant number of the farmers in the study area were not adopted the row planting technology. Therefore, continual campaign using different mass media about the importance of row planting technology must be done. Above all, the authors 
recommend that a practical demonstration work should be done by the government and any concerned stakeholders on farmers training center (FTC) and/or on model farmers' plots.

Farmers should adopt agriculture technology and devote a considerable part of their time for their farming activities which is major means of their livelihood. As shown in Table 4, repetition of plowing and clearing of weeding positively and significantly affect the maize production yield per hectare. Repetition of tillage is essential for the farm to regain soil fertility naturally, and thus, the farmers should be motivated to repeatedly plow their farm. In the same way, repetition of weeding also has similar positive impacts on farming productivity, and hence, the farmers are recommended to control every weed from their farm.

Credit access to farmers should be facilitated above and beyond exerting efforts to raise the farm income in the study area. In addition, the tenure security certificates must also be provided to all farmers to enhance the farmers' confidence on their ownership as well as to increase the investment each farmer made on their farm. The author also recommends the government and/or any concerned stakeholders to provide fertilizer and seed input prior to the farming season, because there is a delay and sometimes a shortage in the supply of the essential farm input in the study area.

\section{Supplementary information}

Supplementary information accompanies this paper at https://doi. org/10.1186/s40066-020-00270-w.

Additional file 1: Annex I. Linktest result for model specification tests of the frontier model.

\section{Abbreviations}

BoARD: Bureau of Agriculture and Rural Development; DEA: Data Envelopment Analysis; DMU: Decision Making Unit; ETB: Ethiopian Birr; OLS: Ordinary Least Square; SFM: Stochastic Frontier Production Model; SFP: Stochastic Frontier Production; MLE: Maximum-Likelihood Estimation; TE: Technical Efficiency; TEM:Technical Efficiency Model; TLU: Tropical Livestock Unit.

\section{Acknowledgements \\ The author is highly grateful to the kebele administrators of the Adola Rede and Ana Sorra Districts and all participants in the study for their contribution in completion of this study. Moreover, the author would also like to appreciate Bule Hora University for providing the required fund for the research work. The author would like to acknowledge all reviewers this paper for their scholarly contribution for improving the quality of the paper.}

\section{Authors' contributions}

The author declares that the entire works of research designing, analysis, and interpretation were done by the author himself. All materials used in the study were duly acknowledged. The author read and approved the final manuscript.

\section{Funding}

This research was conducted by using the fund obtained from Bule Hora University. The University has provided the required fund to the researcher in order to solve the community problem by making a research-based intervention. The university's role is confined only on providing fund and follow up the research work and it has no role in designing of the study and collection, analysis, and interpretation of data and in writing the manuscript.

\section{Availability of data and materials}

The datasets during and/or analyzed during the current study available from the corresponding author on reasonable request.

\section{Ethics approval and consent to participate}

Not applicable.

\section{Consent for publication}

Not applicable.

\section{Competing interests}

The authors declare that they have no competing interests.

Received: 25 February 2020 Accepted: 29 September 2020

Published online: 18 November 2020

\section{References}

1. Abate Bekele MF. Effect of farm size on efficiency of wheat production in Moretna-Jirru district in Central Ethiopia. Ind J Agric Econ. 2009;64(1):133-43.

2. Abdulai PK. Technical efficiency of maize production in Northern Ghana. Afr J Agric Res. 2013;8(43):5251-9.

3. Bempomaa B, Acquah HD. Technical efficiency analysis of maize production: evidence from Ghana. Appl Stud AgribusComm. 2014;8(2-3):73-9.

4. Aigner D, Lovell CAK, Schmidt P. Formulation and estimation of stochastic frontier production models. J Econom. 1977;6:21-37.

5. Alene AD \& RM Hassan (2003) "The determinants of farm-level technical Efficiency among adopters of improved maize production technology in Western Ethiopia." Agrekon, Vol 42, No 1

6. Ali HX-X. Technical efficiency of hybrid maize growers: a stochastic frontier. J Integr Agric. 2019;18(10):2408-21.

7. ATA. Report on area and production of major crops. Annual Report. Addis Ababa, Ethiopia: ATA; 2019.

8. Bamlaku A, Nuppenau EA, Boland H. Technical efficiency of farming systems across agro-ecological zones in Ethiopia: an application of stochastic frontier analysis. Agric J. 2007:4(4):202.

9. Battese GE, Coelli TJ. A model for technical inefficiency effects in a stochastic frontier production function for panel data. Empirical Econ. 1995;20:325-32.

10. Beshir H. Technical efficiency measurement and their differential in wheat production: the case of Smallholder Farmers in South Wollo. Int J Econ Bus Finance. 2016:4(1):1-16 (ISSN: 2327-8188).

11. Beyan A. Analysis of farm households'technical efficiency in production of smallholder. Am Eurasian J Agric Environ Sci. 2013;13(12):1615-21.

12. Beyan A, Jema H, Endrias $G$. Analysis of farm households'technical efficiency in production of smallholder farmers: the case of Girawa District, Ethiopia. J Agric Environ Sci. 2013;13(12):1615-21.

13. CIMMYT(2018) Water Efficient Maize for Africa (WEMA) https://wema.aatfafrica.org/ (https://www.monsanto.com/improving agriculture/ pages/ water-efficient-maize-for-africa.aspx) Accessed 20 Jun 2019.

14. Coelli TJ. Recent Developments in frontier modelling and efficiency measurement. Aust J Agric Econ. 1995;3:219-45.

15. Creswell JW. Educational research: planning, conducting and evaluating quantitative research. 4th ed. Boston, MA: Pearson Education Inc.; 2012.

16. Endrias G, Ayalneh B, Belay K, Eyasu E. Technical efficiency of small holder maize producers in Ethiopia: the case of Wolaita and GamoGofa zones. Awassa: EEA; 2012.

17. FAO. TheStalnsecurity in the World 2013. The multiple dimensions of food security. Rome: FAO; 2013.

18. Farrell MJ. The measurement of productive efficiency. J R Stat Soc Ser A General. 1957;120(3):253-81.

19. Forsund FR, Lovell CAK, Schmidt P. A survey of frontier production functions and of their relationship to efficiency measurement. J Econom. 1980;13(1):5-25. 
20. Geta E, Bogale A, Kassa B, Elias E. Productivity and efficiency analysis of smallholder maize producers in Southern Ethiopia. J Hum Ecol. 2010;41(1):67-75.

21. Getachaw A. Cerael Productivity in Ethiopia: An Analysis Based on ERHS Data. Ethiopian J Econ. 2011;XX(2):1-26.

22. Girma $\mathrm{H}$. Estimation of technical efficiency of dairy farms in central zone of Tigray National Regional State. Heliyon. 2019;5:1-24.

23. Guji Zone. Socioeconomic profile of Guji Zone; 2014.

24. IdrisAkanbiAyinde RO. Technical efficiency of maize production in Ogun State, Nigeria. J Dev Agric Econ. 2015;7(2):55-60.

25. Jianxu Liu SR. Enhancing productivity and resource conservation by eliminating inefficiency of Thai rice farmers: a zero inefficiency stochastic frontier approach. 2017, p 1-18. www.mdpi.com/journal/sustainability.

26. Jondrow J, Lovell KCA, Materov IS, Schmidt P. On the estimation of technical inefficiency in the stochastic frontier production function model. J Econ. 1982;19:233-8.

27. Kalinda JN. A stochastic frontier analysis of technical efficiency of maize production under minimum tillage in Zambia. Res Sustain Agric. 2015:4(2):31-46.

28. Kibirige D. Estimation of technical efficiency among smallholder maize farmers in Uganda: a case study of Masindi District of Uganda. Int J Econ CommManag. 2014;III):1-15.

29. Kumbhakar SC, Knox Lovell CA. Stochastic frontier analysis. Cambridge: Cambridge University Press; 2000
30. Negatu KK. Analysis of levels and determinants of technical efficiency of wheat producing farmers in Ethiopia. Afr J Agric Res. 2016;11(36):3391-403.

31. Oyewo IO. Technical efficiency of maize production in Oyo state. J Econ Int Finance. 2011;3(4):211-6.

32. Parikh A, Shah M. Measurement of technical efficiency in the northwest frontier province of Pakistan. J Agric Econ. 1994;45(1):132.

33. Plessis JD. Maize Production. Agriculture, Republic of South Africa. Pretoria, 0001 South Africa: Printed and published by the Department of Agriculture and obtainable from Resource Centre Directorate Agricultural Information Services. 2003.

34. USAID. Food Assistance Fact Sheet—Ethiopia. 2016.

35. Weldegebriel $\mathrm{H}$. The determinants of technical efficiency of farmers in Teff, Maize and Sorghum production: empirical evidence from Central Zone of Tigray Region. Ethiop J Econ. 2014;13(2):1-36.

36. Walliman N. Social science research methods. London: SAGA Publication; 2006.

\section{Publisher's Note}

Springer Nature remains neutral with regard to jurisdictional claims in published maps and institutional affiliations.
Ready to submit your research? Choose BMC and benefit from:

- fast, convenient online submission

- thorough peer review by experienced researchers in your field

- rapid publication on acceptance

- support for research data, including large and complex data types

- gold Open Access which fosters wider collaboration and increased citations

- maximum visibility for your research: over $100 \mathrm{M}$ website views per year

At BMC, research is always in progress.

Learn more biomedcentral.com/submissions 